\title{
CONSUMER ENGAGEMENT BEHAVIOR PERSPECTIVE IN SOCIAL MEDIA: MEDIATING ROLE AND IMPACT ON BRAND EQUITY
}

\author{
Ligita Zailskaite-Jakste \\ Kaunas University of Technology, Lithuania
}

Inga Minelgaite

University of Iceland

\begin{abstract}
This study analyzes the impact of marketing communication (MC) in social media (SM) on brand equity $(\mathrm{BE})$, seeking to identify the mediating role of consumer engagement behavior (CEB) between generated functional and hedonic content on brand equity (BE). The CEB is divided into three levels: consuming, contributing, and creating. A survey-based empirical study with 401 respondents was conducted in the Eastern Europe country of Lithuania. The five control variables that were implemented disclosed new mediation tracks and the good fit of the model. The main findings of the research are that CEB occurring via SM platforms mediates the relationship between marketing communication and BE.

These outcomes suggest that companies seeking to make an impact on BE through CEB in level creation should develop company-created utilitarian content which may engage consumers, extending the reach of their content and helping to facilitate long-term brand loyalty.
\end{abstract}

Keywords: marketing communication; consumer engagement behavior; social media; brand equity

DOI: http://dx.doi.org/10.15549/jeecar.v8i2.501

\section{INTRODUCTION}

The company and the consumer remain the main marketing communication (MC) participants in sales and marketing (SM), but their positions are different. Consumers have become active participants in MC (Noniashvili, Batiashvili, \& Griffin, 2014), engaged in content about brand creation that is evaluated as more reliable and possessing a stronger impact on other consumers compared to company created content (CCC) (Berthon, Pitt, Plangger and Shapiro, 2012). Therefore, it no is longer enough for companies to use one-way communication to create a clear and rich structure of brand knowledge. Successful communication in SM is nowadays also dependent on consumer engagement behavior (CEB).

Recent studies on the consumer engagement (CE) phenomenon analyze it from different perspectives such as multidimensional (Brodie et al., 2011); psychological (Calder, Isaac and 
Malthouse, 2013), social consumer (Gambetti, Graffigna ir Biraghi, 2012); experimental (Voorveld, Van Noort, Muntinga ir Bronner, et al., 2018), behavioral (Schivinski, Christodoulides \& Dabrowski, 2016; van Doorn et al., 2010).

In this paper, we analyze the CEB perspectives for several reasons. First is the lack of empirical research which analyzes CEB's impact on brand equity (BE). The second reason is the lack of studies investigating the relationship between $\mathrm{MC}$ and $\mathrm{BE}$ through the mediation of CEB.

For the past decade, researchers have been comparing company-created and consumergenerated content, investigating their impacts on BE (Schivinski and Dabrowski, 2015; 2016); company-created content and consumergenerated content, and impacts on brand awareness, hedonic image and online and offline attitudes to brands (Bruhn, Schoenmueller and Schäfer, 2012); and MC impacts on awareness and image (Godey, Manthiou, Pederzoli, Rokka, Aiello, Donvito and Singh, 2016). However, there is still a gap in understanding the impacts of MC on $\mathrm{BE}$ when the communication is examined with respect to CEB.

Our study seeks to test a model that examines the mediating effects of CEB between independent variables, such as MC, through company-created hedonistic (CCHC) and utilitarian (CCUC) content, and consumergenerated content, hedonistic (CGHC) and utilitarian (CGUC), and dependent variables, including $\mathrm{BE}$ dimensions. In addition, we test the model's fit implementing five control variables: gender, age, use experience, channel type and brand category.

The study contributes to the understanding of the phenomena associated with consumers' engagement in brand communication and $\mathrm{BE}$ research.

\section{CONCEPTUAL FRAMEWORK}

\section{$\mathrm{MC}$ as source of $\mathrm{BE}$}

Recent studies have compared consumer communication in SM with corporate communication (Schivinski and Dabrowski, 2015; 2016), identifying consumer communication in SM as a fundamental and primary source of brand knowledge (Bruhn et al. 2012), and a company's communication methods are considered a secondary source of BE. Therefore, we think it is necessary to involve company and consumer communication when organic communication as a source of $\mathrm{BE}$ is analyzed.

In this study, we distinguish three dimensions of BE - awareness, associations, and loyalty which are considered to be equivalent (Aaker, 1996; 2008; Keller, 1993).

Brand awareness is defined as the ability of consumers to recognize or recall the category of goods in which the brand is located (Keller, 1993). Brand associations are what are directly and/or indirectly related to brands in a consumer's mind: thoughts, colors, sounds, feelings, smells, tastes, and consumption situations (Keller, 2003). Brand loyalty includes a commitment to re-purchase and sustain interest in a future product or service, regardless of the situation or marketing actions that may affect behavioral changes (Eelen, Özturan, \& Verlegh, 2017). Loyal consumers in SM can communicate positively about the brand (Kim, Lee and Hiemstra, 2004).

However, consumer generated content (CGC) can adjust the brand identity elements communicated by the company and may not completely match the ones created solely by the company. Despite the fact that integrated MC helps to form unique, strong and beneficial associations in the minds of consumers, leading to a more positive brand image, it is recognized that consumer-based content, based on both positive and negative consumer experience with brands, is difficult to control in SM. It can be assumed that consumer and brand resonance, or active $\mathrm{CE}$, occurs when consumers are willing to engage in the highest level of CEB level.

Based on this study's review, the most frequently analyzed types of content created/generated in SM is functional and hedonic content.

Functional content. The premise of the formation of functional content can be considered the consumer's attitude to the utilitarian or functional properties of the product (Voss, Spangenberg, Grohmann, 2003), also called instrumental features. Examples of functional content include reviews and presentations of products and events (location, time, or purpose of the event) (Shen and Bissell, 
2013). In this way, functional content in SM has cognitive and/or utilitarian characteristics that provide consumers with useful and practically applicable information that helps to solve problems (Jahn and Kunz 2012).

Hedonic content. The type of hedonic content created by the company is associated with fun, entertainment, and the enjoyment of leisure time. We can consider the hedonic qualities of the product as the formation of hedonic content (Voss et al. 2003; Batra and Ahtola, 1991), which cause pleasant sensations based on the consumer's experience (Batra and Ahtola, 1991). Entertainment content encourages consumption, creation and contribution to content creation (Muntinga, Moorman and Smit, 2011).

\section{The conceptualization of CEB in SM}

There are two ways to interpret CEB in SM. One states that consumers' engagement behavior occurs in the context of interactions between enterprises and consumers in SM and is related to behavioral dimensions: valence, (form or modality, scope, and nature of its impact) and consumer goals (Van Doorn et al., 2010). Another aspect includes consumer actions, which are generally classed from low to high (Muntinga et al. 2011, Malthouse et al. 2013). We use this delineation.

In this study, we distinguish three essential levels of CE which are based on a study by Shao (2009) (see Table 1). These CEB levels were used by Yoo and Gretzel (2011), Barger, Peltier and Schultz (2016), and other authors. Similar brandrelated online consumer-related activities (COBRA) are provided by Muntinga et al. (2011). Based on the COBRA model, Schivinski et al. (2016) created a scale for CE in branding in SM. Bitter and Grabner-Kräuter (2016) found that the positive valence posts on the social network Facebook encouraged more active consumers' engagement behavior than negative valence posts. We therefore focused just on positive valence engagement levels.

Table 1. CEB levels.

\begin{tabular}{|l|l|l|}
\hline No & \multicolumn{1}{|c|}{ Levels } & \multicolumn{1}{c|}{ Consumer engagement behavior } \\
\hline 1. & Consuming & $\begin{array}{l}\text { The CEB in the consuming level is obviously invisible. Consumers read } \\
\text { content created by other consumers, searching for the right content. }\end{array}$ \\
\hline 2. & Contributing & $\begin{array}{l}\text { The consumers run content, rate it, post comments, share content, connect } \\
\text { to social networks, and update their profiles. Consumers tend to share } \\
\text { content when they receive it form others but are less inclined to start by } \\
\text { themselves. }\end{array}$ \\
\hline 3. & Creating & $\begin{array}{l}\text { The consumers create and post content about themselves and business in } \\
\text { the different types: texts, photos, audio and video, moderate communication } \\
\text { and actively develop content in communities, care each other. }\end{array}$ \\
\hline
\end{tabular}

In this study, CEB communicating in SM is defined as consumers' actions which are oriented toward companies, brands or other consumers and resulting from consumer needs.

\section{CONCEPTUAL MODEL AND HYPOTHESES}

The research focuses on the analysis of the direct content created in SM and its impacts on BE. Schivinski and Dąbrowski (2015) found that consumer-generated communication has a positive effect on the three dimensions of $\mathrm{BE}$ : brand awareness/associations, brand loyalty, and perceived quality. Schivinski and Dąbrowski (2016) revealed that brand attitude has a stronger impact on $\mathrm{CE}$ in the non-alcoholic beverage sector compared to the clothing and telecommunication sectors. Bruhn et al. (2012) identified that company communication in SM has a stronger impact on the functional brand image, and CGC affects the hedonic brand image more. The results of the study also revealed that the impact of communication on the dimensions of $\mathrm{BE}$ differs by business sector. Kim and Ko (2012) found that MC in SM has an impact on the $\mathrm{BE}$, which in turn has a positive impact on 
purchasing intentions. Godey et al. (2016) revealed that MCs in SM have a positive effect on brand awareness and image, although the results of the study revealed that MCs using SM have a similar effect on all dimensions of BE.

The following set of hypotheses (Table 2) have been developed.

Table 2. Hypotheses.

\begin{tabular}{|c|c|c|}
\hline $\mathrm{H} 1$ & $\begin{array}{l}\text { CEB consumption } \\
\text { (H1a), contribution } \\
\text { (H1b), and creation } \\
\text { (H1c) mediates the } \\
\text { positive effect of } \\
\text { CGH content on BE } \\
\text { dimensions }\end{array}$ & $\begin{array}{l}\text { (H1aa; H1ba; } \\
\text { H1ca) } \\
\text { awareness, } \\
\text { (H1ab; H1bb; } \\
\text { H1cb) } \\
\text { associations, } \\
\text { (H1ac, H1bc; } \\
\text { (H1cc) loyalty }\end{array}$ \\
\hline $\mathrm{H} 2$ & $\begin{array}{l}\text { CEB consumption } \\
\text { (H2a), contribution } \\
\text { (H2b), and creation } \\
\text { (H2c) mediates the } \\
\text { positive effect of } \\
\text { CGF content on BE } \\
\text { dimensions }\end{array}$ & $\begin{array}{l}\text { (H2aa; H2ba, } \\
\text { H2ca) } \\
\text { awareness, } \\
\text { (H2ab; H2bb; } \\
\text { H2cb) } \\
\text { associations, } \\
\text { (H2ac; H2bc; } \\
\text { H2cc) loyalty }\end{array}$ \\
\hline H3 & $\begin{array}{l}\text { CEB consumption } \\
\text { (H3a), contribution } \\
\text { (H3b), and creation } \\
\text { (H3c) mediates the } \\
\text { positive effect of } \\
\text { CHH content on BE } \\
\text { dimensions }\end{array}$ & $\begin{array}{l}\text { (H3aa; H3ba; } \\
\text { H3ca) } \\
\text { awareness, } \\
\text { (H3ab; H3bb; } \\
\text { H3cb) } \\
\text { associations, } \\
\text { (H3ac; H3bc; } \\
\text { H3bc) loyalty }\end{array}$ \\
\hline $\mathrm{H} 4$ & $\begin{array}{l}\text { CEB consumption } \\
\text { (H4a), contribution } \\
\text { (H4b), and creation } \\
\text { (H4c) mediates the } \\
\text { positive effect of } \\
\text { CCF content on BE } \\
\text { dimensions }\end{array}$ & $\begin{array}{l}\text { (H4aa; H4ba; } \\
\text { H4ca) } \\
\text { awareness, } \\
\text { (H4ab; H4bb; } \\
\text { H4cb) } \\
\text { associations, } \\
\text { (H4ac; H4bc; } \\
\text { H4cc) loyalty. }\end{array}$ \\
\hline
\end{tabular}

There remains a lack of studies which evaluate the impacts of indirect MCs on BE. The consumers' engagement behavior can strengthen or weaken impact on BE. Some suggestions to analyze impact marketing orientation on BE through CEB can be found in the theoretical study of Ngai, Tao and Moon (2015). Hollebeek, Glynn, and Brodie (2014), applying a multi-dimensional CE perspective, found that consumer-brand engagement mediates the associations between the independent variable of consumer brand 'involvement' and the dependent variable of consumer 'self-brand connection'.

\section{STUDY DESIGN}

\section{Sample}

To test our hypotheses, we used a quantitative method for assessing the mediation role of CEB levels between company and consumers' communication in SM and to examine $\mathrm{BE}$ dimensions. The survey was conducted between July and October of 2017, with the questionnaire uploaded to the web page www.surveymonkey.com. The questionnaire link was posted on the personal profile of the article authors on Facebook, Google+, LinkedIn and Supermama.It. In total, 2545 questionnaires were started but only 401 questionnaires were fully completed.

Overall, 108 brands were grouped into five categories, including services, products, places, personalities, and retailers (De Chernatony, 2010). We did not attach to one or several brands in this research, but rather gave the respondents the opportunity to choose the brand they are involved in. Such a choice is implied by the practice of research related to communication in SM. The sample consisted of $58.85 \%$ males and $41.15 \%$ females.

The seven-point Likert scale was used in the questionnaire, ranging from 'completely disagree' (1) to 'fully agree' (7) (Aaker, Kumar, and Day 2007), which is still referred to as the total measurement scale.

For the measurement of hedonic and functional consumer-generated content and company created content, the selected scale was adapted from the works of Voss et al. (2003), Hennig-Thurau, Walsh and Walsh (2003), Jahn and Kunz (2012)), Bruhn et al. (2012), Shao and Ross (2015), Schivinski and Dąbrowski (2015, 2016). Consumers' engagement behavior was measured using Schivinski et al. (2016) proposed scale. For brand awareness, measurement was conducting using the scale adopted by Yoo et al. 
(2000), Bruhn et al. (2012), and Schivinski and Dąbrowski (2015). For associations, the scale was taken from Verhoef et al. (2007), and Aaker (1996); for loyalty, the scale was adopted from Yoo et al. (2000), De Vries and Carlson (2014), Aaker (1996).

\section{Data analysis strategy}

The analyses were conducted with Mplus version 7.31 (Muthen and Muthen, 1998-2015) using robust maximum likelihood (MLR) estimation (Satorra and Bentler, 1994) within a structural equation model framework. Model fit was evaluated using Comparative Fit Index (CFI) and the Root Mean Square Error of Approximation (RMSEA). CFI values higher than .90 are indicative of an acceptable fit, with values higher than .95 suggesting an excellent or very good fit. RMSEA values lower than .05 indicate good or close fit, and values as high as .08 represent acceptable errors of approximation (Little, 2013). In addition, we examined the $90 \%$ confidence interval of the RMSEA: The model fit can be considered acceptable when the upper bound of this confidence interval is no greater than .10 (Kline,
2016). As is conventional, we reported the ChiSquare statistic; however, we did not use it to test the model fit since it is well-known that this statistic is overly sensitive to trivial influences in moderately large samples (e.g., Little, 2013).

In the first step, to examine the psychometric characteristics of study constructs, we tested one global measurement model containing all latent variables (Figure 1, Model 2). In other words, we conducted confirmatory factor analysis (CFA) of all constructs in one model. Next, the main effects of the hypothesized model (Figure 1, Model 1) were tested with structural equation modeling (SEM). In the final step, to test the mediational model (Figure 1, Model 1) the hypothesized mediators were added to the SEM. Following the advancements in the methodological literature, the mediational paths were tested even though the direct paths were not significant (Hayes, 2009). The bias-corrected bootstrapped 95\% confidence intervals of the indirect effect were then estimated to confirm the significance of a possible mediation. The mediation is considered significant when confidence interval does not include zero.

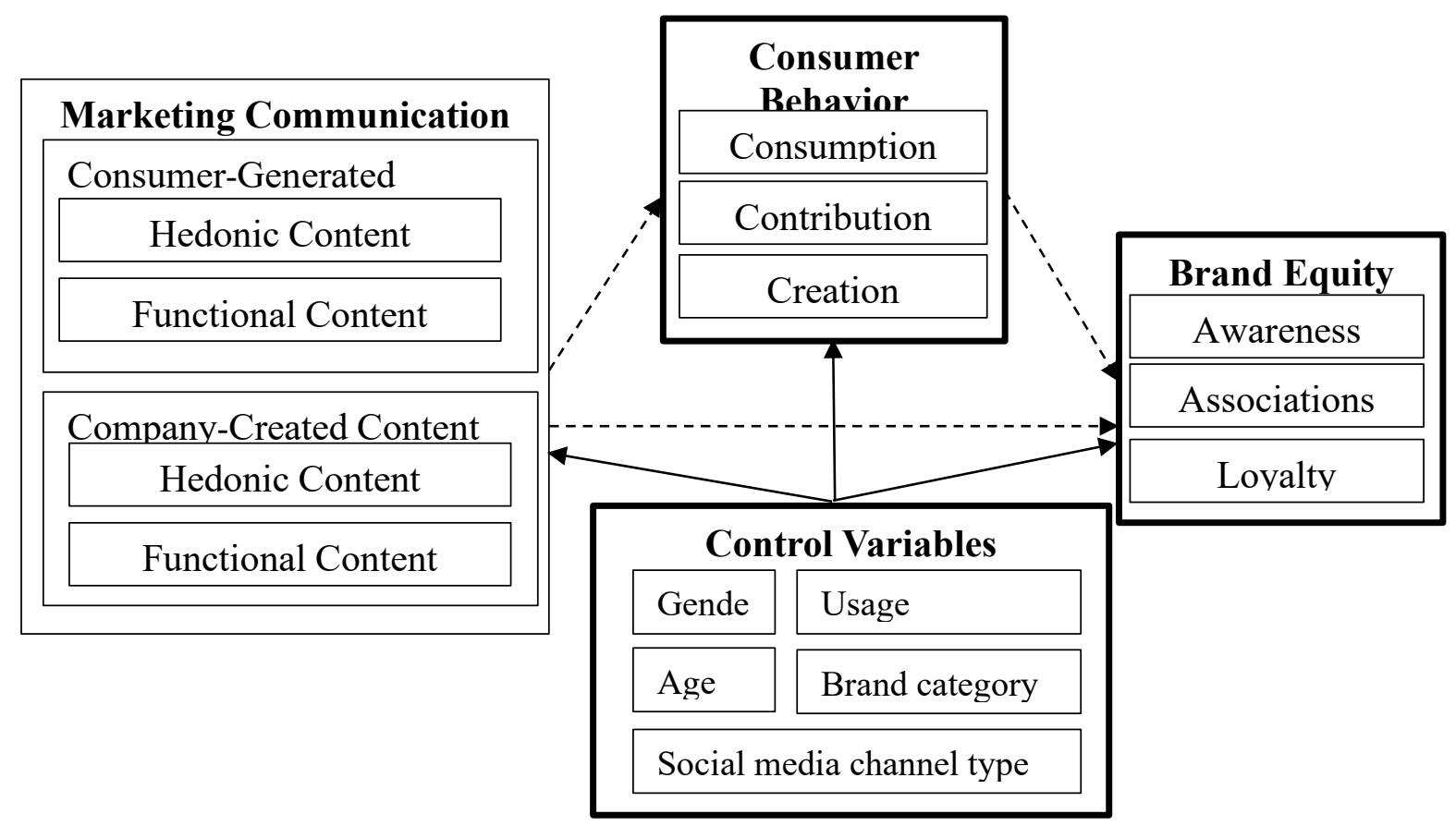

Figure 1. Conceptual Model of CCC and CGC different types of impact on BE dimensions through CEB. Model 1 represented by solid line; Model 2 represented by solid and dashed lines together. 


\section{RESULTS}

\section{Preliminary Analysis}

All measures were found to be highly reliable. The psychometric properties of the scales were assessed through Cronbach's $\alpha$. Descriptive statistics, reliability coefficient and the correlations between the variables are shown in Table 3.

\section{Confirmatory Factor Analysis}

The CFA of all study variables yielded poor model fit $\left(\chi^{2}(815)=1953.23, \mathrm{CFI}=.879\right.$, RMSEA $=.059[.056, .062])$, thus, in the second step we allowed to co-vary 13 pairs of latent variables indicators. The pairs of indicators were from the same latent variables and/or had a good theoretical reason to be correlated (e.g. the same items resembled in company created and consumer generated content). The adjusted measurement model fitted data well $\left(\chi^{2}(802)=\right.$ 1499.80$, CFI $=.926$, RMSEA $=.047[.043, .050])$.

\section{Test of Main Effects}

In addition to the hypothesized antecedents of the $M C$ and outcomes of $B E$, we added five control variables: gender, age, usage experience, brand category, and SM channel type. The model fitted data well $\left(\chi^{2}(457)=836.05\right.$, CFI $=.933$, RMSEA $=.045[.041, .050])$. This set of predictor variables explained 18\%, $30 \%$ and $41 \%$ of Awareness, Associations, and Loyalty variance respectively. The standardized parameter estimates for the main effects of the model are shown in Table 4.

\section{Mediation Analysis}

To test the final model in the next step we included CEB Levels as a mediator between the $M C$ and $B E$ while controlling for gender, age, usage experience, brand category, and SM channel type (Figure 1, M2). The final model fitted data well $\left(\chi^{2}(1009)=1857.48, C F I=.916\right.$, RMSEA $=.046[.043, .049])$. Direct paths of the model are reported in Table 4.

Table 3. Descriptive statistics, reliability and correlations between measures

\begin{tabular}{|c|c|c|c|c|c|c|c|c|c|c|c|c|}
\hline Variable & 1 & 2 & 3 & 4 & 5 & 6 & 7 & 8 & 9 & $M$ & $S D$ & Cronbach $\alpha$ \\
\hline 1. IKT_F & - & & & & & & & & & 4.13 & 1.36 & .80 \\
\hline 2. IKT_H & .19 & - & & & & & & & & 4.31 & 1.43 & .80 \\
\hline 3. VKT_F & .65 & .15 & - & & & & & & & 4.36 & 1.61 & .90 \\
\hline 4. VKT_H & .25 & .70 & .36 & - & & & & & & 4.21 & 1.59 & .89 \\
\hline 5. K & .29 & .14 & .30 & .30 & - & & & & & 2.58 & 1.67 & .94 \\
\hline 6. D & .31 & .24 & .28 & .37 & .68 & - & & & & 3.60 & 1.59 & .89 \\
\hline 7. $\mathrm{V}$ & .30 & .34 & .37 & .42 & .28 & .48 & - & & & 5.10 & 1.32 & .79 \\
\hline 8. Z & .09 & .29 & .06 & .20 & -.01 & .17 & .37 & - & & 5.96 & 1.04 & .84 \\
\hline 9. A & .26 & .42 & .23 & .43 & .16 & .33 & .50 & .61 & - & 5.41 & 1.17 & .89 \\
\hline 10. L & .36 & .33 & .43 & .45 & .47 & .56 & .50 & .35 & .62 & 4.61 & 1.33 & .84 \\
\hline
\end{tabular}

After the inclusion of mediators, the model explained 35\%, $42 \%$ and $60 \%$ of Awareness, Associations, and Loyalty variance, respectively. Additionally, some of the paths became weaker or disappeared at all, suggesting partial or full mediation. Furthermore, to examine significant indirect effects, and in this way to prove potential mediation, we conducted the bootstrapping procedure with 10,000 samples. The significant estimated standardized and unstandardized results and unstandardized 95\% confidence intervals are presented in Table 5. 
Table 4. Standardized regression coefficients from the Model 1 (direct model) and Model 2 (mediated model)

\begin{tabular}{|c|c|c|c|c|c|c|}
\hline \multirow{3}{*}{ /Outcome } & \multicolumn{3}{|c|}{ Model 1 (direct model) } & \multicolumn{3}{|c|}{ Model 2 (mediated model) } \\
\hline & $\mathrm{Z}$ & A & $\mathrm{L}$ & $\mathrm{Z}$ & A & $\mathrm{L}$ \\
\hline & \multicolumn{3}{|c|}{$\boldsymbol{\beta}$} & \multicolumn{3}{|c|}{$\beta$} \\
\hline \multicolumn{7}{|l|}{ Predictor/ } \\
\hline IKT_F & n.s. & $.20^{*}$ & n.s. & n.s. & $.15^{*}$ & n.s. \\
\hline IKT_H & $.39^{* *}$ & $.27^{*}$ & $.21^{*}$ & $.37^{* *}$ & $.27^{* *}$ & $.19^{* *}$ \\
\hline VKT_F & n.s. & n.s. & $.27^{* *}$ & n.s. & n.s. & $.18^{* *}$ \\
\hline VKT_H & n.s. & $.21^{*}$ & $.21^{*}$ & $-.31^{* *}$ & n.s. & n.s. \\
\hline
\end{tabular}

Note. ${ }^{*} \mathrm{p}<.05,{ }^{* *} \mathrm{p}<.01$.

Table 5. Standardized parameter estimates and $95 \%$ confidence intervals of Model 2 (mediated model) indirect effects

\begin{tabular}{|l|l|l|l|}
\hline \multicolumn{1}{|c|}{ Indirect path } & \multicolumn{1}{|c|}{$\begin{array}{c}\text { Estimate of an } \\
\text { indirect effect } \\
\text { (standardized) }\end{array}$} & $\begin{array}{c}\text { Estimate of an } \\
\text { indirect effect } \\
\text { (unstandardized) }\end{array}$ & $\begin{array}{c}\text { 95\% confidence } \\
\text { interval }\end{array}$ \\
\hline IKT_F -> K -> Z & -.04 & -.03 & {$[-.05,-.01]$} \\
\hline IKT_H -> K -> Z & .03 & .02 & {$[.01, .06]$} \\
\hline IKT_H -> V -> Z & .10 & .07 & {$[.01, .17]$} \\
\hline VKT_F ->V -> Z & .16 & .09 & {$[.05, .14]$} \\
\hline VKT_H -> K -> Z & -.05 & -.03 & {$[-.07,-.01]$} \\
\hline IKT_H -> V -> A & .09 & .09 & {$[.01, .21]$} \\
\hline VKT_F ->V -> A & .15 & .11 & {$[.06, .18]$} \\
\hline IKT_F -> K -> L & .06 & .06 & {$[.02, .10]$} \\
\hline IKT_F -> D -> L & .04 & .04 & {$[.01, .07]$} \\
\hline IKT_H -> K -> L & -.05 & -.05 & {$[-.10,-.01]$} \\
\hline IKT_H -> V -> L & .07 & .07 & {$[.01, .29]$} \\
\hline VKT_F ->V -> L & .11 & .09 & {$[.04, .16]$} \\
\hline VKT_H -> K -> L & .09 & .07 & {$[.03, .13]$} \\
\hline VKT_H -> D -> L & .05 & .04 & {$[.01, .09]$} \\
\hline
\end{tabular}

Note. Only effects of that confidence interval do not contain zero are reported.

The results confirmed fourteen significant indirect mediational paths. Creation partly mediated the relationship between $\mathrm{CCHC}$ and Awareness, between CGHC and Awareness, and between CCHC and Loyalty. And fully mediated the relationship between CCUC and Awareness with Loyalty, and between CGHC and Loyalty. Contribution fully mediated the relationship 
between CCUC and Loyalty, and between CGHC and Loyalty. Consumption partly mediated the relationship between CCHC and all levels of $\mathrm{BE}$, and between CGUC and Loyalty, and fully mediated the relationship between CGUC and Awareness with Associations. All mediational paths supported the hypotheses except one: negative mediation of Creation between $\mathrm{CCHC}$ and Awareness.

\section{Discussion of results}

\section{CONCLUSIONS}

Researchers agree that $\mathrm{BE}$ is an element of competitive advantage and is formed over the long-term. Therefore, the identification of the factors which may enhance this competitive element is of considerable importance. Especially, SM stimulates companies to extend their understanding about the sources of $\mathrm{BE}$ and to think about the CEB role in the MC process. Even the CGC in SM may have a stronger influence on others' CEB compared to companies' created content.

The theoretical analysis discussed that there is a lack of studies that would justify the CEB communicating in SM, including all three engagement levels in the $M C$ area with respect to BE. From our point of view, MC in SM goes through CEB, therefore it is necessary to evaluate this engagement impact on $\mathrm{BE}$.

The empirical analysis found that creation fully mediated the relationship between CCUC and awareness with loyalty, and between CGHC and loyalty. Contribution fully mediated the relationship between CCUC and loyalty, and between CGHC and loyalty. These results suggest that the CCC, which gave practical, helpful, and useful information, may strengthen impacts on brand awareness and loyalty formation through CEB via communications using SM. CGC related with fun, happiness, and entertainment about brands, and this may strengthen impact on brand loyalty through consumers' engagement behavior level creation.

We looked to MC impacts on BE from a consumers' perspective. The reason for choosing such a perspective was based on careful analysis of the existing scientific literature.

We contribute to the branding literature by facilitating more integrated understanding about underlying factors which influence BE communication using SM. This research reveals the power of consumers' engagement behavior in SM. The current research suggests that consumers' engagement behavior is valuable in all three levels, but CEB in the contribution and creation levels may extend companies' communication in SM and lead to broader consumer reach for brand loyalty formation.

\section{Limitations and further research}

First, we focused just on the Lithuanian market; cultural differences may provide deeper understanding of CEB communicating in SM seeking positive impact on $\mathrm{BE}$.

Second, we analyzed just positive $\mathrm{CM}$ on brand equity. The impact of negative valence CEB and the change from positive CEB to negative CEB may provide deeper understanding about the reasons for brand dilution.

Third, this study related the communication in SM impact on three individual dimensions of the $\mathrm{BE}$ without analyzing the impact of consumer involvement on the overall $\mathrm{BE}$.

Fourth, we used just the CEB perspective in this study, and other CE perspectives, such as multidimensional, psychological, social, and experiential, may enable revelations about CE impacts on BE through other dimensions.

Fifth, we concentrated just on organic communication, excluding other types of communication, which is acknowledged as a source of BE as well.

Last, we conducted the survey in 2017. A repeated survey and a comparison of its results with this study's sample may provide further insights, especially considering the rapid changes of consumers' engagement behavior impacts on $\mathrm{MC}$ and $\mathrm{BE}$. BE is formed over the long-term and therefore day-to-day consumer encounters with particular brands in SM may strengthen the structure of knowledge in their minds.

\section{REFERENCES}

Aaker, D. A. (1996). Measuring brand equity across products and markets. California management review, 38(3), 102. 
Aaker, D. A. (2008). Strategic market management. John Wiley \& Sons.

Aaker, D.A., V. Kumar, and G.S. Day. 2007. Marketing Research. Ninth Edit. Danvers MA: John

Ashley, C., \& Tuten, T. (2015). Creative strategies in social media marketing: An exploratory study of branded social content and consumer engagement. Psychology \& Marketing, 32(1), 15-27.

Barger, V., Peltier, J. W., \& Schultz, D. E. (2016). Social media and consumer engagement: a review and research agenda. Journal of Research in Interactive Marketing, 10(4), 268-287.

Batra, R., \& Ahtola, O. T. (1991). Measuring the hedonic and utilitarian sources of consumer attitudes. Marketing letters, 2(2), 159-170.

Berthon, P. R., Pitt, L. F., Plangger, K. \& Shapiro, D. (2012). Marketing meets Web 2.0, social media and creative consumers: Implications for international marketing strategy. Business horizons, 55(3), 261-271.

Bitter, S., \& Grabner-Kräuter, S. (2016). Consequences of customer engagement behavior: when negative Facebook posts have positive effects. Electronic Markets, 26(3), 219-231.

Brodie, R. J., Hollebeek, L. D., Jurić, B., ir Ilić, A. (2011). Customer engagement: Conceptual domain, fundamental propositions, ir implications for research. Journal of Service Research, 14(3), 252-271.

Bruhn, M., Schoenmueller, V., \& Schäfer, D. B. (2012). Are social media replacing traditional media in terms of brand equity creation?. Management Research Review, 35(9), 770-790.

Calder, B. J., Isaac, M. S., \& Malthouse, E. C. (2013). Taking the customer's point-ofview: Engagement or satisfaction? Marketing Science Institute Working Paper Series 2013. Report no 13-102.

Christodoulides, G., \& De Chernatony, L. (2010). Consumer-based brand equity conceptualization and measurement: A literature review. International journal of research in marketing, 52(1), 43-66.
De Chernatony, L. (2010). Creating powerful brands. Routledge.

De Vries, N. J., \& Carlson, J. (2014). Examining the drivers and brand performance implications of customer engagement with brands in the social media environment. Journal of Brand Management, 21(6), 495515.

Dholakia, U. M., Bagozzi, R. P., \& Pearo, L. K. (2004). A social influence model of consumer participation in network-and small-group-based virtual communities. International journal of research in marketing, 21(3), 241-263.

Dolan, R., Conduit, J., Fahy, J., \& Goodman, S. (2015). Big social data and social media analytics: tools for exploring social media engagement behaviour. In 2015 ANZMAC Conference: Innovation and Growth Strategies in Marketing. ANZMAC c/o School of Marketing, UNSW Business School, UNSW Australia.

Eelen, J., Özturan, P., \& Verlegh, P. W. (2017). The differential impact of brand loyalty on traditional and online word of mouth: The moderating roles of self-brand connection and the desire to help the brand. International Journal of Research in Marketing, 34(4), 872-891.

Godey, B., Manthiou, A., Pederzoli, D., Rokka, J., Aiello, G., Donvito, R., \& Singh, R. (2016). Social media marketing efforts of luxury brands: Influence on brand equity and consumer behavior. Journal of business research, 69(12), 5833-5841.

Hayes, A. F. (2009). Beyond Baron and Kenny: Statistical Mediation Analysis in the New Millennium. Communication Monographs, 76, 408-420. doi:10.1080/03637750903310360.

Heinonen, K. (2011). Consumer activity in social media: Managerial approaches to consumers' social media behavior. Journal of Consumer Behaviour, 10(6), 356-364.

Hennig-Thurau, T., Walsh, G., \& Walsh, G. (2003). Electronic word-of-mouth: Motives for and consequences of reading customer articulations on the Internet. International journal of electronic commerce, 8(2), 51-74. 
Hollebeek, L. D., Glynn, M. S. \& Brodie, R. J. (2014). Consumer brand engagement in social media: Conceptualization, scale development and validation. Journal of Interactive Marketing, 28(2), 149-165. doi:10.1016/j.intmar.2013.12.002.

Jahn, B., \& Kunz, W. (2012). How to transform consumers into fans of your brand. Journal of Service Management, 23(3), 344-361.

Keller, K. L. (1993). Conceptualizing, measuring, and managing customer-based brand equity. the Journal of Marketing, 1-22.

Keller, K. L. (2003). Brand synthesis: The multidimensionality of brand knowledge. Journal of consumer research, 29(4), 595600.

Kim, A. J., \& Ko, E. (2012). Do social media marketing activities enhance customer equity? An empirical study of luxury fashion brand. Journal of Business Research, 65(10), 1480-1486.

Kim, W. G., Lee, C., \& Hiemstra, S. J. (2004). Effects of an online virtual community on customer loyalty and travel product purchases. Tourism management, 25(3), 343-355.

Kline, R. B. (2016). Principles and practice of structural equation modeling (4th ed.). Guilford publications.

Little, P. T. D. (2013). Longitudinal structural equation modeling. Guilford Press.

Malthouse, E. C., Haenlein, M., Skiera, B., Wege, E., \& Zhang, M. (2013). Managing customer relationships in the social media era: Introducing the social CRM house. Journal of Interactive Marketing, 27(4), 270-280.

Muntinga, D. G., Moorman, M., \& Smit, E. G. (2011). Introducing COBRAs: Exploring motivations for brand-related social media use. International Journal of Advertising, 30(1), 13-46.

Muthén, L. K. \& Muthén, B. O. (1998-2015). Mplus user's guide (7th ed.). Los Angeles, CA: Muthén \& Muthén.

Noniashvili, M., Batiashvili, M., \& Griffin, G. (2014). THE USE OF SOCIAL MEDIA IN THE REPUBLIC OF GEORGIA AND A DISCUSSION ABOUT AMERICAN ACADEMIC FREEDOM WITH ELECTRONIC COMMUNICATIONS.
Journal of Eastern European and Central Asian Research, 14.

Ngai, E. W., Tao, S. S. \& Moon, K. K. (2015). Social media research: Theories, constructs, and conceptual frameworks. International Journal of Information Management, 35(1), 33-44.

Satorra, A., \& Bentler, P. M. (1994). Corrections to test statistics and standard errors in covariance structure analysis. In A. von Eye \& C. C. Clogg (Eds.), Latent variables analysis: Applications for developmental research (pp. 399-419). Thousand Oaks, CA: Sage.

Schivinski, B. \& Dabrowski, D. (2015). The impact of brand communication on brand equity through Facebook. Journal of Research in Interactive Marketing, 9(1), 3153.

Schivinski, B. \& Dabrowski, D. (2016). The effect of social media communication on consumer perceptions of brands. Journal of Marketing Communications, 22(2), 189-214.

Schivinski, B., Christodoulides, G., \& Dabrowski, D. (2016). Measuring consumers' engagement with brand-related socialmedia content: Development and validation of a scale that identifies levels of socialmedia engagement with brands. Journal of Advertising Research, 56(1), 64-80.

Shao, G. (2009). Understanding the appeal of user-generated media: a uses and gratification perspective. Internet Research, 19(1), 7-25.

Shen, B., \& Bissell, K. (2013). Social media, social me: A content analysis of beauty companies' use of Facebook in marketing and branding. Journal of Promotion Management, 19(5), 629-651.

So, K. K. F., King, C., Sparks, B. A., \& Wang, Y. (2016). The role of customer engagement in building consumer loyalty to tourism brands. Journal of Travel Research, 55(1), 64-78.

Van Doorn, J., Lemon, K. N., Mittal, V., Nass, S., Pick, D., Pandner, P., \& Verhoef, P. C. (2010). Customer engagement behavior: Theoretical foundations and research directions. Journal of Service Research, 13(3), 253-266. 
Verhoef, P. C., Langerak, F., \& Donkers, B. (2007). Understanding brand and dealer retention in the new car market: The moderating role of brand tier. Journal of retailing, 83(1), 97113.

Voss, K. E., Spangenberg, E. R., \& Grohmann, B. (2003). Measuring the hedonic and utilitarian dimensions of consumer attitude. Journal of marketing research, 40(3), 310320.

Yoo, B., Donthu, N. \& Lee, S. (2000). An examination of selected marketing mix elements and brand equity. Journal of the academy of marketing science, 28(2), 195211.

Yoo, K. H., \& Gretzel, U. (2011). Influence of personality on travel-related consumergenerated media creation. Computers in Human Behavior, 27(2), 609-621.

\section{ABOUT THE AUTHORS}

Ligita Zailskaite-Jakste, email: ligzail@ktu.lt

Dr. Inga Minelgaite is a Professor at School of Business, University of Iceland. Inga is also visiting professor and/or board member at few other Universities in Europe. Her main field of research is cross-cultural leadership, including in temporary teams, e.g., projects. Inga is co-author of the first book on business leadership in Iceland "Demystifying leadership in Iceland" (Springer). Inga is active in research dissemination and cooperation with industry, as business consultant and speaker.

Dr. Ligita Zailskaitè-Jakštė is a researcher, lecturer, and project manager at the Kaunas University of Technology. Her main field of research is consumer engagement behavior in social media in the context of business and education. She reads lectures about marketing, journalism, and humancomputer interaction. Ligita worked for more than 10 years as a marketing and communication specialist at the Kaunas University of Technology. 